This is an Accepted Manuscript of an article published by Taylor \& Francis in Journal of Marketing Management on 03/09/18, available online:

https://www.tandfonline.com/doi/full/10.1080/0267257X.2018.1512516 


\section{Financial Charity Giving Behaviour of the Working Poor: An Empirical Investigation}

Roger Bennett

Kingston University London*

Kingston Business School, Kingston University, Kingston Hill, Kingston Upon

Thames, KT2 7BL. Email: R.Bennett@kingston.ac.uk. Tel: 020884179000.

*The research relating to the current paper was undertaken while the author was a professor and director of the Centre for Research in Marketing at London Metropolitan University.

The author

Dr Roger Bennett is a professor of marketing at Kingston Business School. Roger's main research interests lie in the field of non-profit and voluntary sector marketing, especially in relation to fund-raising and the marketing management of non-profit organisations. 


\title{
Financial Charity Giving Behaviour of the Working Poor: An Empirical \\ Investigation
}

\begin{abstract}
Although it is well-known that, on the average, financially poor individuals donate higher percentages of their incomes to charity than do the financially well-off, little research has been completed into possible differences in the financial giving behaviour of poor people in employment (the working poor) and poor individuals of working age who do not work. The present study addresses this issue via a survey of working and unemployed poor people in three low-income Boroughs in inner-London: Newham, Hackney and Tower Hamlets. It is hypothesised that disparities can be explained by, among other things, factors connected with a poor person's sense of engagement with the wider society; in conjunction with an individual's experiences and perceptions of social deprivation. Outcomes to the investigation suggest that the working poor tend to exhibit attitudes and behaviour more similar to those of the financially better-off than to the non-working poor, and that their affinity with the betteroff extends to their donating lower percentages of their incomes to charity than the unemployed poor.
\end{abstract}

Key words: charity fundraising, working poor, social exclusion, social deprivation, selfconcept, self-esteem.

\section{Summary statement of contribution}

The study applies the theory of social exclusion to the analysis of charity donation behaviour among a sample of working poor people in three socially deprived London Boroughs. It examines the roles of a person's sense of social inclusion and the individual's self-concept as a socially deprived member of a community as determinants of the proportion of a donor's income given to charity. Findings indicate that the working poor participants in the study 
contributed significantly lower amounts of their incomes to charity than those who were long-term unemployed.

\section{Introduction}

A substantial volume of research undertaken on both sides of the Atlantic has established that, on the average, financially poor people donate proportionately more of their incomes to charity than better-off individuals (e.g., Ward, 2001; Dilworth; 2013; Pudelek, 2013; Stern, 2013). From a variety of sources, it seems that the average percentage of income donated by the poor is around three to 3.5\%, and by the well-off about one per cent (for details see, for example, Banks and Tanner, 1997; Walker and Pharoah, 2002; Slack, 2005; Wiepking, 2007; Brooks, 2008; Bennett, 2012). Research has shown moreover that observed differences cannot be attributed to overrepresentations of young or elderly people in samples. Arguably, the former might expect their incomes to rise in the future and hence may give generously now even though they are currently poor (Andreoni, 2006), while older people have been found to be more generous than the middle-aged (Sargeant and Woodliffe, 2007). Studies have concluded, however, that low-income old and young individuals tend to give proportionately more of their incomes to charity than wealthier old and young donors (Walker and Pharoah, 2002; CAF/NCVO, 2008).

A gap in the literature exists however concerning possible differences in the possible differences in the average percentages of income donated by employed poor people (the 'working poor), and poor individuals of working age who do not work. Rather, prior research has focused mainly on (i) profiling the characteristics of the working poor and assessing their numbers (e.g., US Department of Labour, 2009; Brady, Fullerton and Cross, 2010, Browne and Hood, 2016), (ii) establishing how the working poor perceive their jobs and relate to their employers (e.g., Leana, Mittal and Stiehl, 2012), (iii) reporting the financial problems 
faced by the working poor (e.g., Morris, 2014; Padley and Hirsch, 2017), and (iv) analysing government policy towards the working poor (e.g., EurWork, 2010) and, in particular, the effects of the situation on children (e.g., Belfield, Cribb, Hood and Joyce, 2015). At the time of writing only two studies have explicitly examined the role of employment status vis-à-vis the giving behaviour of low-income people, but generated conflicting results. Brooks’ (2008) reported US survey findings that the working poor on average donated more than three times as much to charity than non-working poor people with similar levels of income. Conversely a UK study completed by Bennett (2012) found little difference between the donation levels of poor individuals who were and were not in paid employment.

Research into the giving behaviour of the working poor is important considering the dramatic rise in the number of working poor individuals residing in the UK (see below) and in other countries. Fundraisers need to understand the nature of this vital donor market in order to address efficiently and professionally, the requirements of the segment. CAF (2015) reported that although people in the highest (A/B) social categories account for $51 \%$ of all donations there remains a 'long tail' of donations emanating from financially less well-off people who, as stated above, give relatively generously. McKenzie and Pharoah (2011) estimated that nearly $20 \%$ of adults in the lowest decile of the UK population (measured in terms of household expenditure) give to charity on a regular basis and that people in the bottom 30\% account for $12 \%$ of the total value of UK charity gifts made by individuals.

The current research helps fill this crucial gap in the fundraising literature via a study designed to help establish both the characteristics and the philanthropic motives of the working poor in relation to the segment's donation behaviour. Knowledge of these matters should assist fundraising managers when attempting to attract donations from this particular segment, to understand the sensitivities of working poor individuals where charity giving is concerned and hence to service these donors properly, and to assess more accurately the 
(potentially substantial) ‘donor lifetime value’ of employed people who currently are poor but whose earnings may subsequently increase.

The rise of the working poor

Twenty-one per cent of the UK population live below the official poverty line (defined as household income below $60 \%$ of median UK household income after housing costs) (see Walker, 2016) and, by 2014/15, 6.9 million of the 13.5 million people who were in poverty resided in a family where someone worked (McGuiness, 2016). Two-thirds of all British children who live in poverty live in a household where at least one person works (Bingham, 2016). Sixty-four per cent of all employees residing in working poor families in 2014 were paid less than the UK living (rather than the statutory minimum) wage, and 1.4 million worked on employment contracts that did not guarantee minimum hours (Topham, 2014). The household incomes of 4.4 million of the UK's working poor families are 'topped up' by state benefits and/or tax credits; notably housing benefit, council tax benefit, working and child tax credits, employment and work support allowances, and income support (DWP, 2016). However, rising private sector housing rents and government caps imposed on housing benefits have worsened the financial situations of working poor families (Butler, 2017). Earnings at the upper end of the UK earnings distribution have been predicted to rise between 2017 and 2021, but earnings at the lower end of the distribution are forecast to remain stagnant (Browne and Hood, 2016). Clearly, the working poor represent a significant and substantial part of the population, and will continue to do so for the foreseeable future.

\section{The current investigation}

The research outlined below examined two main questions concerning the charity donation behaviour of working and unemployed poor people. (In the present study the term 
'unemployed' refers to longer term unemployment rather than to situations where a person is temporarily out of work, as defined later in the paper.)

RQ1. Do significant differences exist between the average percentage of income given to charity by working poor individuals and by working age unemployed poor individuals?

RQ2. What are the relative strengths of the influences of certain variables associated with the amounts given to charity by working poor and by working age unemployed poor individuals?

These questions are predicated on the possibility that working poor people might adhere to societal norms and customs comparable to the norms and customs of the financially betteroff, as opposed to those of the unemployed poor. Hence it is suggested that the working poor are likely to exhibit a pattern of charity giving behaviour more similar to that of the better-off than to that of the unemployed poor. If this is the case, then the average proportion of income donated to charity by the working poor may be expected to be somewhat lower than the average given to charity by poor people who do not work.

Figure 1 presents the conceptual model used in the investigation based on the abovementioned considerations and containing the five main hypotheses tested in the course of the study. The model proposes that the equivalised (see below) percentage of a person's equivalised income given to charity (EQ\% of EQ income given) depends on the individual's employment status and on the covariates listed, with SDSC and social integration (SI) mediating the influence of employment status on the dependent variable.

\section{Theoretical framework}

Reasons advanced for the difference in the average percentage if income given to charity by the rich and the poor include possibilities that the financially well-off (i) are more likely than the poor to prioritise their own self-interests above the wellbeing of others (Stern, 2013), (ii) 


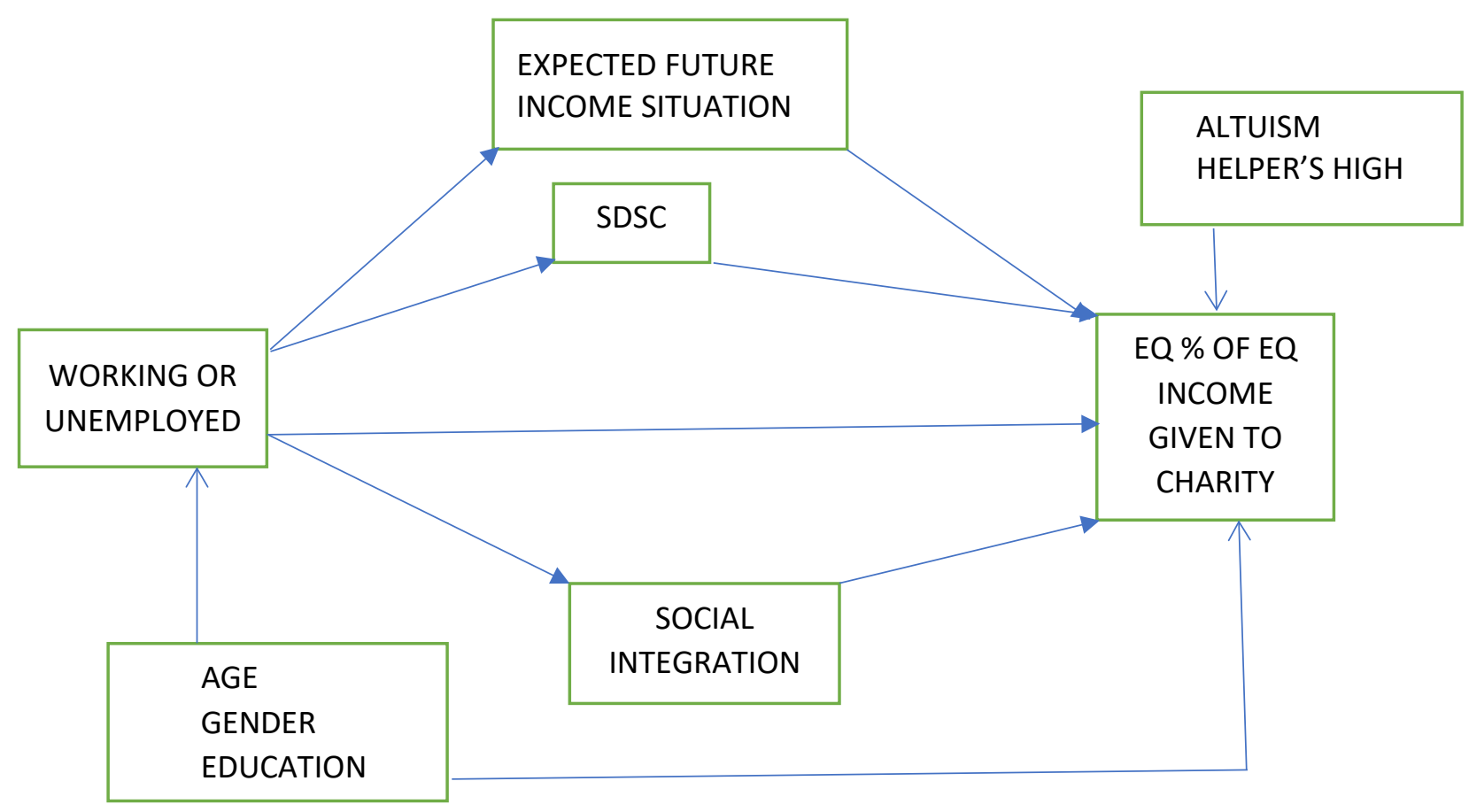

have a greater tendency to want to accumulate wealth (Savchuk, 2014), (iii) experience firsthand the problems dealt with by charities less frequently, and/or (iv) have less empathy with the suffering of the less well-off in need (Bennett, 2012; Savchuk, 2014). The latter suggestion is reinforced by survey findings that wealthy people tend not to support charities that serve the poor and the dispossessed, and vice versa for the poor (see Ostrower, 1997; Radley and Kennedy, 1995; Bennett, 2003; CAF/NCVO, 2008). Piff et al. (2010) reported an 'emerging body of literature' which concluded that personal engagement with the 'needs of others', as opposed to 'focusing on one’s own welfare', best explained giving behaviour among low social class individuals (p. 771).

The theory of social exclusion (see Mathiesson et al., 2008) posits that reductions in personal resources, often associated with unemployment, can lead to feelings of lack of self-worth and low social self-confidence, and that these feelings can affect behaviour. Social exclusion is 'the phenomenon where particular people have no recognition by, or voice or stake in, the 
society in which they live' (Charity Commission, 2001, p. 2), resulting in their 'feeling out of place in society' (p.3). In time, according to (Barnes, 2005), the socially excluded are likely to come to believe that they have been 'shut out, fully or partially from the economic, social and cultural systems that determine the integration of an individual in society’ (p. 15). The unemployed poor in particular are denied access to certain opportunities and resources available to other groups but which are fundamental to social integration (Silver, 1994). Mathieson et al. (2008) observed how social exclusion arising from unemployment 'creates a lens through which people look at reality' (p.2), with consequent implications for behaviour. A study undertaken by the Council of Europe also noted how social exclusion resulting from unemployment often meant that, in addition to not participating in economic life, individuals felt unable to take part effectively in social and cultural activities and that this would cause them to become alienated and distant from mainstream society [Duffy, 1995]). Arguably, the long-term unemployed poor represent 'a group of people at the bottom of the class structure who have become structurally separate and culturally distinct from the regularly employed working class’ (Wilson, 1997 p. 14). Such considerations suggest:

Hypothesis 1. Working poor individuals tend to experience a greater sense of social inclusion than people who are (longer term) unemployed.

In contrast with the longer term unemployed, the working poor might not regard themselves as culturally and socially distinct from mainstream society. Paid work is not only a principal source of income; it is also (according to a study undertaken by the World Bank [2013]) the basis of an individual's core identity, sense of embeddedness in society, and feelings of dignity and self-esteem. Ehrenreich (2001) noted the possibility that financially poor people who are in paid employment may have a greater sense of personal worth than poor people who are unemployed and feel less socially excluded and less stigmatised (Brooks, 2002). If this is in fact the case, it might be the consequence of those at work being more engaged with 
society than the unemployed; more able to control their own lives; and perceiving themselves to be 'respectable, hardworking and aspiring members of consumer society' (Hamilton et al., 2014 p.1834). Importantly, the working poor might experience a deeper sense of participation in consumer society (Bauman, 2005) and these sentiments, according to Hamilton et al. (2014), could induce the working poor to mimic more closely the spending and consumption practices of the financially better-off. It is relevant to note in this connection that many investigations have concluded that media portrayals of the poor are frequently negative Hamilton et al., 2014); focusing on, for example, the debilitating effects of deprivation, low levels of education of poor people, issues to do with crime etc., yet without differentiating between the working and the non-working poor (Bullock, Wyche and Williams, 2001; Horwitz, 2012; Larsen and Dejgaard, 2012). Representations of this type might encourage working poor individuals to want to distance themselves from the unemployed poor. A study completed by Chase and Walker (2013) concluded that financially poor families were acutely aware of negative media stereotyping that emphasised individual rather than structural causes of poverty, resulting in some poor people (notably the working poor) seeking to distinguish and remove themselves from other poor individuals, e.g., via differences in patterns of consumption.

Also, to the extent that the working poor are 'less separated from much that comprises the “normal” round of living and working in a society'; are more in touch with 'the labour market, the marketplace and many aspects of communal life’' (O’Brian, Wilkes, De Haan and Maxwell, 2009 p.3) and are more likely to be included in social circles, networks and support communities of the financially better-off (Hill, 2002), their charity giving behaviour might be anticipated to be closer to that of the financially better-off than to that of the unemployed poor. In practical terms, this could involve their donating a lower proportion of their income, 
even where the income level of a working poor person is similar to that of a non-working poor person. This implies:

Hypothesis 2. Working poor individuals tend to donate a lower percentage of their income to charity than people who are (longer term) unemployed.

\section{Perceptions of social deprivation}

It has been argued that, because the poor in general are closer to social problems such as bad housing, inadequate diet, low calibre medical care, vulnerability to crime, etc., they are acutely aware of the existence of social deprivation (Mayo and Tinsley, 2009). Moreover, according to Rodriguez (2002), the poor as a social group frequently have attitudes based on perceptions of group subordination that can result in their adopting an adversarial stance towards the wider society (see also Steele, 1998). This can lead to poor individuals experiencing not only strong feelings of being socially deprived, but also a greater community spirit (Brooks, 2008). Piff et al. (2010) observed how lower-class individuals often (i) 'orientate towards the welfare of others (of the same class) as a means for adapting to a hostile environment', and (ii) exhibit greater commitment to egalitarian values that encourage solidarity with other lower-class people (p. 771). To the extent that the poor witness at first hand more suffering than the financially better-off and, in consequence, are more aware of unfairness in society, they might respond by donating generously (in relative terms) to charity (Sargeant and Woodliffe, 2007).

An empirical study undertaken by Bennett (2012) concluded that some poor people hold discernible self-concepts as individuals who are economically and socially deprived and that a self-concept of this nature (i.e., a 'socially deprived self-concept' [SDSC]) could influence a poor person’s charity donation behaviour. Specifically, low-income people with high SDSCs (for whom feelings of being poor and deprived are central to their self-identity) might 
feel a deeper sense of association with other poor people than low SDSC individuals and hence may be more willing to give to charities that seek to ameliorate problems that poor people face. However, differences could exist between perceptions of social deprivation held by working and by unemployed poor people. To the degree that the working poor are more connected with the wider economy and society than the unemployed poor it could be that the working poor are more likely to ascribe their current poverty not to social injustice, but simply to circumstance and chance (Radley and Kennedy, 1992). Thus, connectedness and engagement with the labour market and with the wider community may cause the working poor to sense that they are victims of social unfairness to a lesser extent than possibly occurs among the unemployed poor. Accordingly, the working poor might not regard themselves as belonging to a socially deprived community to the same extent as may happen among the unemployed poor. The latter, on the other hand, might see themselves as members of a homogeneous socially deprived group that shares a common destiny. Feelings of social exclusion, social disadvantage and marginalisation that relegate the unemployed poor to the fringe of society could, according to Silver (1994), cause the unemployed poor to experience a sense of solidarity with other disadvantaged people not experienced by the working poor.

Accordingly, it is hypothesised that:

Hypothesis 3. Working poor individuals tend to have lower socially deprived self-concepts (SDSCs) than people who are (longer term) unemployed.

In general, nevertheless, a low-income person with a high SDSC might experience a deeper sense of association with other poor people than a low SDSC individual (cf. Reed, 2004) and hence may be more willing to give to charitable organisations that seek to ameliorate problems that poor people face (cf. Harper and Tuckman, 2006). 
Hypothesis 4. A high level of SDSC is positively associated with the percentage of income donated to charity.

Separately and independently of SDSC, moreover, feelings of social inclusion or exclusion (possibly unrelated to perceptions of deprivation) might affect donation behaviour. Working poor individuals might not believe that they are part of a socially deprived group to the same degree as unemployed poor individuals. Hence, It is posited that:

Hypothesis 5. A strong sense of social inclusion is negatively associated with the percentage of income given to charity.

\section{Covariates}

The above constitute the main hypotheses tested in the current research. In addition to the variables covered by the five hypotheses, two critical considerations known to influence charity giving in general, notably innate altruistic inclination and 'helper’s high' (i.e., the 'warm glow' experienced in consequence of giving to charity) could affect giving levels independently of whether a person was employed or unemployed (Sargeant, 1999; Sargeant and Woodliffe, 2007; Bekkers and Wieping, 2011) and hence were included in the study. An individual's anticipated future income was also incorporated into the analysis, considering that individuals who presently have low incomes may expect their incomes to rise in the future. Thus, currently low levels of income might not impact on levels of charity giving as heavily as otherwise might be the case (Brooks, 2002). The unemployed poor might hold lower expectations than the working poor of the levels of their long-term incomes. It is relevant to note in this connection that predictions of future earnings will depend substantially on uncertainties regarding future unemployment (Lerner, 2013). Such ambiguities could be an especially important consideration among the working poor, given the large number of working poor individuals who work on casual employment contracts. If 
working poor people expect their incomes to rise and if, in particular, they anticipate they will continue to be in paid employment for the foreseeable future then, a priori, they might be predicted to exhibit charity donation behaviour similar to the financially better-off, i.e. to give a smaller proportion of their income to charity than the long-term unemployed poor.

Religiosity was not entered into the model because, although a study of 247 students in a UK university conducted by Skarmeas and Shabbir [2011] found a significant link between religiosity and intention to donate to charity; little empirical evidence has emerged of religiosity affecting donation levels among low-income non-student UK donors - for details see CAF/NCVO [2008] Table 12 p. 27 and Bennett [2012].) An individual's highest educational qualification, age and gender were employed as control variables on the grounds that they could be associated with a person's capacity to obtain a job (Bekkers and Wieping, 2011).

\section{Methodology}

A questionnaire was drafted and administered to a sample of 231 working and 239 unemployed poor people (as previously defined) across three socially deprived London Boroughs: Newham, Hackney and Tower Hamlets, areas that have some of the highest levels of social deprivation in Western Europe and which contain a fifth of all the people in the bottom $20 \%$ of the UK income distribution (ONS, 2017). Pensioners were excluded from the sample, as was anyone living in a household with an equivalised household income (see below) of more than $60 \%$ of the median for Greater London. Following the practice of (among others) the US Department of Labour (2009), a person was regarded as 'working' if (a) the individual had been in employment for at least 27 weeks during the past year, and (b) defined themselves as people who were 'normally in work' (thus removing individuals who may have experienced a single ad hoc six-month period of employment but were not usually 
in employment). Anyone who normally worked for less than 28 hours a week was not included in the study (cf. ILO, 2015).

Data was collected by a research assistant, a work placement intern and two cohorts of volunteer marketing research students during two semesters (29 students in the first class and 26 in the second). Many of the students resided in the three Boroughs. The students undertook the task (for which training was provided) as part of an optional course assignment. Each student was asked to obtain ten completed questionnaires (about two hours' work) for each category of respondent through street interviews around job centres, health clinics, post offices or Metro stations in the three Boroughs; or alternatively from people in the areas known to the student and who satisfied the low-income criteria (neighbours, contacts provided by friends, etc.). The respondents were coded into groups according to the type of person that had conducted the interview (student, intern, or research assistant) and, for the students, in terms of whether the interviewee was previously known by the person concerned. An examination of the results arising from the various groups did not reveal any meaningfully significant differences in patterns of outcomes.

\section{Measurement of variables}

A 'poor' person was defined in terms of the characterisation applied by the UK government's Department of Work and Pensions, i.e., as someone who lives in a household that receives less than $60 \%$ of the median equivalised household income within the UK as a whole. It is necessary to consider 'household' income because an individual's standard of living depends not only on his or her own income but also on the incomes of others in a household (Micklewright and Schnepf, 2007), given that income sharing within a household typically takes place. The UK Department for Work and Pensions employs OECD (Organisation for Economic Co-operation and Development) scales for 'equivalising' household incomes to 
take into account variations in household sizes and compositions (see DWP, 2009 Appendix 2). Equivalisation attempts to compensate for the fact that a certain level of income going into, for instance, a single adult person household will afford the resident a higher standard of living than the same level of income received by a household containing two adults. (Specifically, it is assumed that $67 \%$ of a particular level of income is sufficient to maintain a single person at the standard of living equivalent to that enjoyed by each individual in a twoperson household receiving the same total amount.) Annually, the DWP publishes equivalised figures for all family sizes and compositions with respect to number of children under age 16 and other dependent relatives. In line with British government practice since 2004 when measuring poverty, the study used OECD equivalised household incomes after tax and before housing costs.

The strength of a respondent's self-concept as a socially deprived person (SDSC) was measured through a scale created for this purpose by Bennett (2012). An example of the nine items in the (five-point agree/disagree) scale is 'I believe that society treats people with low incomes very unfairly’. Unlike Bennett’s (2012) findings, where a factor analysis generated two factors within the nine items, factor analyses of the two sets of participants' responses in the present study (working poor and unemployed poor) revealed unidimensional solutions in both cases (lambda $=6.4$, Cronbach’s alpha $=.87$ for the first group and lambda $=6.6$, Cronbach's alpha $=.89$ for the second). A person's sense of integration with the wider society was assessed via five items (five-point scales) adapted from Lee and Robbins' (1995) Social Connectedness scale. Sample items from the scale are 'I feel disconnected from the society around me' and 'I feel very distant from the world of paid work'. Again, factor analyses of responses generated unidimensional solutions (lambda $=4.0$; Cronbach’s alpha $=.85$ and lambda $=3.9$; Cronbach’s alpha $=.83$ ). Altruistic inclination was measured using six items from a scale developed and validated by Bennett and Barkensjo (2005) on the basis 
of prior instruments constructed by Schwartz (1977) (lambda=4.6; Cronbach’s alpha=.83 and lambda=4.0; Cronbach's alpha=.8)). The scale items queried whether a person felt a 'strong moral obligation towards the welfare of others', a strong sense of social responsibility, commitment to a just world, pleasure when helping others, and whether others would regard the individual as considerate and caring (p. 278).

Helper's high was assessed through four items adapted from Bennett and Gabriel (1999) (lambda=3.1; Cronbach’s alpha=.87 and lambda=3.0; Cronbach’s alpha=.82), i.e., whether donating to charity gave the person 'a huge amount of pleasure', deep personal satisfaction, feelings that 'my own life is made better' and whether not giving would cause guilty feelings (p. 55). Anticipated future income was evaluated by a single (five-point) agree/disagree item worded 'I expect my income will increase by quite a lot in the future'. Following standard practice (CAF/NCVO, 2008; CAF, 2015), giving behaviour was measured by asking the participant the question 'In how many months during the last six months do you recall having given to charity, and on average how much was given?’. Additionally, the questionnaire collected information on a person’s age, gender, highest educational qualification, household size and composition (numbers of adults, children and dependents), and approximate average weekly household income (equally divided into 20 categories up to $£ 600$ a week).

\section{Data analysis and interpretation}

On average, the $46 \%$ of the sample who were female gave approximately the same as males. Although studies of UK charity giving have usually concluded that males donate about six or seven per cent more on average than females (due presumably to the presence within samples of greater numbers of high income men than high income women), this was not the case in the present study of low income people. Half of all the individuals approached by the interviewers stated that they had made a charitable donation in the previous month; a figure broadly comparable for the UK population as a whole (see CAF, 2015). Donors in the 
combined sample had given an average of $£ 65.5$ per person in the last six months and on average recalled having given to charity in three of the previous six months. Table 1 outlines the main characteristics of the sample.

It can be seen from Table 1 that, on the average, the working poor individuals in the sample had significantly $(\mathrm{p}<.05)$ lower SDSC scores and higher scores for the social integration

TABLE 1. SAMPLE CHARACTERISTICS

\begin{tabular}{|c|c|c|}
\hline & Working poor & Unemployed poor \\
\hline Median age (years) & 38 & 41 \\
\hline $\begin{aligned} \text { Amount given in last six months } \\
-\quad \text { Mean average } \\
-\quad \text { Median } \\
\end{aligned}$ & $\begin{array}{c}£ 60 \\
£ 22.5\end{array}$ & $\begin{array}{c}£ 70.5 \\
£ 27\end{array}$ \\
\hline $\begin{array}{l}\text { Amount given in last six months by people } \\
\text { in the lowest quarter of the distribution of } \\
\text { equivalised incomes } \\
\text { - Mean average } \\
\text { - } \quad \text { Median }\end{array}$ & $\begin{array}{l}£ 54 \\
£ 21\end{array}$ & $\begin{array}{l}£ 58.5 \\
£ 23.4\end{array}$ \\
\hline $\begin{aligned} & \text { Mean values of: } \\
& \text { - } \text { SDSC composite } \\
& \text { - } \text { Social integration composite } \\
& \text { - } \text { Altruism composite } \\
& \text { - } \text { Helper's high composite } \\
&\end{aligned}$ & $\begin{array}{l}2.4 \\
3.0 \\
3.3 \\
2.8\end{array}$ & $\begin{array}{l}2.9 \\
2.5 \\
3.2 \\
3.0\end{array}$ \\
\hline $\begin{array}{l}\text { Mean annual equivalised income per } \\
\text { individual in a household }\end{array}$ & $£ 6,086$ & $£ 5,705$ \\
\hline $\begin{array}{l}\text { Average \% of equivalised household income } \\
\text { given to charity }\end{array}$ & 1.97 & 2.56 \\
\hline $\begin{array}{l}\text { Average equivalised \% of equivalent } \\
\text { household income given to charity }\end{array}$ & 2.11 & 2.77 \\
\hline $\begin{array}{l}\text { Mean of item relating to expected future } \\
\text { increases in income }\end{array}$ & 2.5 & 2.4 \\
\hline 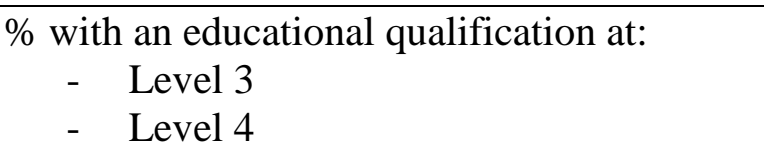 & $\begin{array}{l}56 \% \\
44 \%\end{array}$ & $\begin{array}{l}39 \% \\
28 \%\end{array}$ \\
\hline
\end{tabular}

composite. Expectations of increased future incomes were about the same for both the employed and unemployed poor. (This outcome is perhaps unsurprising given that the study was completed at a time when the household incomes of poor people in the UK had remained approximately constant for nearly ten years.) The working poor had on average donated less 
to charity during the previous six months than the non-working poor (median $£ 22.5$ compared with £27) and on an annual basis had given a lower percentage of their equivalised annual incomes to charity, in both absolute terms (1.97\% as opposed to $2.56 \%)$ and when the amounts donated are expressed in equivalised values. (Equivalisation of the amounts given is a relevant exercise as a donation of, say, $£ 50$ in absolute terms, is relatively less generous for a person whose equivalised income is such that the individual in question does not need much money to live on.) The working poor in the sample had higher equivalised incomes on average than the unemployed and were better educated. Table 1 shows the proportions of the two groups possessing level 3 and level 4 qualifications. In the UK, a level 3 qualification equates to an educational achievement obtained beyond basic secondary school (leaving age 16) but below matriculation. Level 4 qualifications relate to the educational level normally associated with the first year of a college degree. This result indicates that the better educated people in the sample had better chances of getting a job.

Table 2 presents the correlations between (i) the amounts given to charity by each of the groups over a six-month period and (ii) the other variables covered by the investigation. Average variance extracted and composite reliability statistics are given alongside the correlation coefficients. The Table shows that the average amount donated by both groups was positively associated with a person's SDSC and with equivalised income, and negatively with the social integration variable. (Axiomatically the level of the amount donated correlated positively with the proportion of income donated.) Age, educational level and expected future income did not correlate significantly with the average amount given. SDSC was, as anticipated, negatively connected with social integration and positively associated with the proportion of income donated. The more socially integrated a person the lower the proportion of income given. Correlations between average amount donated and SDSC and between amount donated and social integration were stronger among the unemployed poor. Also, 
employed people with higher incomes were likely to donate a lower proportion of their income than working people at the bottom of the income spectrum. Altruism and helper's high correlated significantly with the giving variables, as anticipated a priori. Being male was not associated with higher income in the present sample, where incomes were generally low and women were likely to receive maternity and child care benefits not available to males.

Test of the hypotheses

A number of the variables in the model depicted in Figure 1 were not normally distributed and the sample size was modest. Accordingly, the model was initially tested using the method of partial least squares and employing the SmartPLS software package for the estimation. This initial test generated satisfactory diagnostic measures for the estimated model. Variance inflation factors for all the variables were less than value five, indicating the absence of problems connected with multicollinearity. All average variance extracted statistics exceeded all inter-construct correlations and all HTMT statistics were less than value six, confirming the presence of discriminant validity among the independent variables. Initial estimations showed that certain variables failed to attain significance ( $>>.6)$ as determinants of the percentage of income donated irrespective of any combination of other regressors, i.e., age, educational level, gender, and expected future income. Moreover, age and gender failed to impact significantly ( $>$ >.44) on the likelihood that a participant would be employed. The insignificance of age indicates that unemployment affected all the age groups covered by the study approximately equally). Gender was not significant largely in consequence of the way the data was gathered, i.e., approximately equal percentages of working and unemployed females. Whether a person was employed or unemployed did not significantly influence $(p=.35)$ expected future income. In consideration of these initial analyses, educational level was not used as an explanatory variable vis-à-vis percentage of income, and expected future 


\section{TABLE 2. CORRELATION MATRIX}

Values shown are for the working poor with values for the unemployed poor in parentheses. Average variances extracted and composite reliabilities are shown after the diagonals of the four latent variables.

\begin{tabular}{|c|c|c|c|c|c|c|c|c|c|c|c|c|}
\hline 1. $\quad$ Average amount donated & 1 & & & & & & & & & & & \\
\hline 2. Age & $\begin{array}{l}.10 \\
(.12)\end{array}$ & 1 & & & & & & & & & & \\
\hline 3. $\quad$ SDSC (mean of composite) & $\begin{array}{c}.36^{*} \\
(.44)^{*}\end{array}$ & $\begin{array}{l}.15 \\
(.15)\end{array}$ & 1 & $\begin{array}{l}.70 \\
.78\end{array}$ & $\begin{array}{l}.80 \\
.78\end{array}$ & & & & & & & \\
\hline $\begin{array}{l}\text { 4. Social integration (mean of } \\
\text { composite) }\end{array}$ & $\begin{array}{l}-.24 * \\
(-.29)^{*}\end{array}$ & $\begin{array}{c}.06 \\
(-.05)\end{array}$ & $\begin{array}{l}-.27 * \\
(-.31)^{*}\end{array}$ & 1 & $\begin{array}{l}.69 \\
.70\end{array}$ & $\begin{array}{l}.78 \\
.76\end{array}$ & & & & & & \\
\hline 5. Equivalised income & $\begin{array}{l}.44^{*} \\
(.49)^{*}\end{array}$ & $\begin{array}{l}.16 \\
(.18)\end{array}$ & $\begin{array}{l}-.10 \\
(-.13)\end{array}$ & $\begin{array}{l}.19 \\
(.19)\end{array}$ & 1 & & & & & & & \\
\hline $\begin{array}{ll}6 . & \% \text { of equivalised household } \\
\text { income given to charity }\end{array}$ & $\begin{array}{l}.61^{*} \\
(.58)^{*}\end{array}$ & $\begin{array}{l}.11 \\
(.16)\end{array}$ & $\begin{array}{l}.40^{*} \\
(.48)^{*}\end{array}$ & $\begin{array}{l}-.38 * \\
(-.30)^{*}\end{array}$ & $\begin{array}{l}-.29 * \\
(.11)\end{array}$ & 1 & & & & & & \\
\hline $\begin{array}{l}\text { 7. Equivalised \% of equivalised } \\
\text { household income given to } \\
\text { charity }\end{array}$ & $\begin{array}{l}.65^{*} \\
(.66)^{*}\end{array}$ & $\begin{array}{l}09 \\
(.10)\end{array}$ & $\begin{array}{l}.44^{*} \\
(.49)^{*}\end{array}$ & $\begin{array}{l}-.36^{*} \\
(-.24)^{*}\end{array}$ & $\begin{array}{l}-.29 * \\
(-.30)^{*}\end{array}$ & $\begin{array}{l}.80^{*} \\
(.77)^{*}\end{array}$ & 1 & & & & & \\
\hline $\begin{array}{ll}\text { 8. } & \begin{array}{l}\text { Expected future increases in } \\
\text { income }\end{array} \\
\end{array}$ & $\begin{array}{l}.12 \\
(.16)\end{array}$ & $\begin{array}{c}.06 \\
(.09)\end{array}$ & $\begin{array}{l}.16 \\
(.16)\end{array}$ & $\begin{array}{l}.08 \\
(.11)\end{array}$ & $\begin{array}{l}.09 \\
(.09)\end{array}$ & $\begin{array}{l}.10 \\
(.13)\end{array}$ & $\begin{array}{l}.11 \\
(.12)\end{array}$ & 1 & & & & \\
\hline $\begin{array}{l}\text { 9. Has a level } 4 \text { educational } \\
\text { qualification }\end{array}$ & $\begin{array}{l}.08 \\
(.08)\end{array}$ & $\begin{array}{c}-.34 * \\
(-.30)^{*}\end{array}$ & $\begin{array}{l}-.30 * \\
(-.29)^{*}\end{array}$ & $\begin{array}{l}.30^{*} \\
(.11) \\
\end{array}$ & $\begin{array}{l}.19 \\
(.10) \\
\end{array}$ & $\begin{array}{l}.10 \\
(.08) \\
\end{array}$ & $\begin{array}{c}.09 \\
(.09) \\
\end{array}$ & $\begin{array}{l}.18 \\
(.06) \\
\end{array}$ & 1 & & & \\
\hline 10. Altruism (mean of composite) & $\begin{array}{l}.44^{*} \\
(.45)^{*}\end{array}$ & $\begin{array}{c}.04 \\
(.09) \\
\end{array}$ & $\begin{array}{l}-.04 \\
(.06)\end{array}$ & $\begin{array}{l}.10 \\
(.13)\end{array}$ & $\begin{array}{c}.10 \\
(.12) \\
\end{array}$ & $\begin{array}{l}.43^{*} \\
(.46)^{*}\end{array}$ & $\begin{array}{l}.39 * \\
(.31)^{*}\end{array}$ & $\begin{array}{l}.13 \\
(.16) \\
\end{array}$ & $\begin{array}{c}.02 \\
(-.10) \\
\end{array}$ & 1 & $\begin{array}{l}.67 \\
.71 \\
\end{array}$ & $\begin{array}{l}.80 \\
.78 \\
\end{array}$ \\
\hline $\begin{array}{l}\text { 11. Helper's high (mean of } \\
\text { composite }\end{array}$ & $\begin{array}{l}.36^{*} \\
(.30)^{*} \\
\end{array}$ & $\begin{array}{l}.13 \\
(.15) \\
\end{array}$ & $\begin{array}{l}.08 \\
(.11) \\
\end{array}$ & $\begin{array}{c}.03 \\
(.06) \\
\end{array}$ & $\begin{array}{l}.19 \\
(.19) \\
\end{array}$ & $\begin{array}{l}.35^{*} \\
(.39)^{*} \\
\end{array}$ & $\begin{array}{l}.40^{*} \\
(.38)^{*}\end{array}$ & $\begin{array}{l}.18 \\
(.11) \\
\end{array}$ & $\begin{array}{c}.01 \\
(.03)^{*}\end{array}$ & $\begin{array}{l}.46^{*} \\
(.48)^{*}\end{array}$ & $\begin{array}{l}.69 \\
.72 \\
\end{array}$ & $\begin{array}{l}.78 \\
.79 \\
\end{array}$ \\
\hline 12. Gender (male $=1)$ & $\begin{array}{l}-.03 \\
(.07)\end{array}$ & $\begin{array}{l}-.01 \\
(.09) \\
\end{array}$ & $\begin{array}{l}.12 \\
(.10)\end{array}$ & $\begin{array}{c}.14 \\
(.10)\end{array}$ & $\begin{array}{c}.08 \\
(-.07)\end{array}$ & $\begin{array}{l}-.04 \\
(.10) \\
\end{array}$ & $\begin{array}{l}.12 \\
(.04) \\
\end{array}$ & $\begin{array}{l}.13 \\
(.03) \\
\end{array}$ & $\begin{array}{c}.06 \\
(-.02)\end{array}$ & $\begin{array}{l}.10 \\
(.11)\end{array}$ & $\begin{array}{l}.05 \\
(.03) \\
\end{array}$ & 1 \\
\hline
\end{tabular}

* Indicates significance at the .01 level or below. Row 12 contains point biserial correlations. 
income, age and gender were removed from the estimation entirely. The insignificance of age and gender as potential determinants of the percentage of income donated might be explained by the participants' job and income situations being equally uncertain for both sexes and for all age groups. Expected future income may have been insignificant because wage levels among the poor had been approximately constant for nearly ten years, with media reports suggesting that this situation would continue in the future (especially in the public sector). Only $13 \%$ of the participants believed that their incomes would rise. (Current income levels could not be used as a regressor as its inclusion would mean that the same variable appeared both as an independent variable and as the denominator of the dependent variable, causing bias in the estimated coefficients.) There was no evidence of interaction effects involving altruism and helper's high significantly affecting any of the pathways shown in Figure 1. As the reduced model involved just two mediating pathways plus two covariates (altruism and helper’s high), the five main hypotheses were tested using Hayes’ (2013) PROCESS analysis macro for SPSS (Hayes Model 4 with dichotomous antecedent variable [Hayes, 2013 p. 128]). The Hayes (2013) macro generates robust bias corrected bootstrapped standard errors for the products of regression coefficients in mediated pathways hence enabling the significance of the pathways to be reliably assessed. For multiple mediator models the macro provides a simultaneous test of each mediating mechanism while accounting for the shared association between them (p.131). The results of this analysis are presented in Table 3. (The effect of education level on the likelihood that a person would be employed or unemployed was measured separately within the initial SmartPLS estimation and, confirming the correlation in Table 2, was significant [regression coefficient $=.24 ; \mathrm{T}=2.5$; $\mathrm{p}=.04$ ].) Table 3 shows that being employed rather than unemployed exerted a negative and substantial main effect on the percentage of income donated ( $\mathrm{b}=-.44$ ), thus confirming $\mathrm{H} 2$, and that $41.3 \%$ of the variance in the dependent variable is accounted for by a person's employment status in conjunction 
with the two mediators. The specific indirect effect obtained from the Hayes model 4 macro for the mediated pathway from employment status to percentage of income through SDSC was significant ( $\mathrm{b}_{1} \mathrm{~b}_{2}=-.1$, bootstrapped $\left.\mathrm{T}=3.01\right)$; as was the impact of the specific indirect 
TABLE 3. PARAMETER ESTIMATES

\section{Consequent}

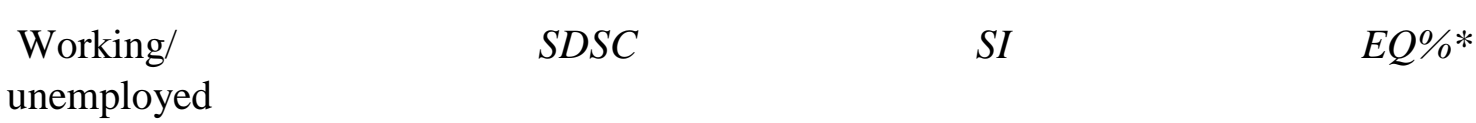

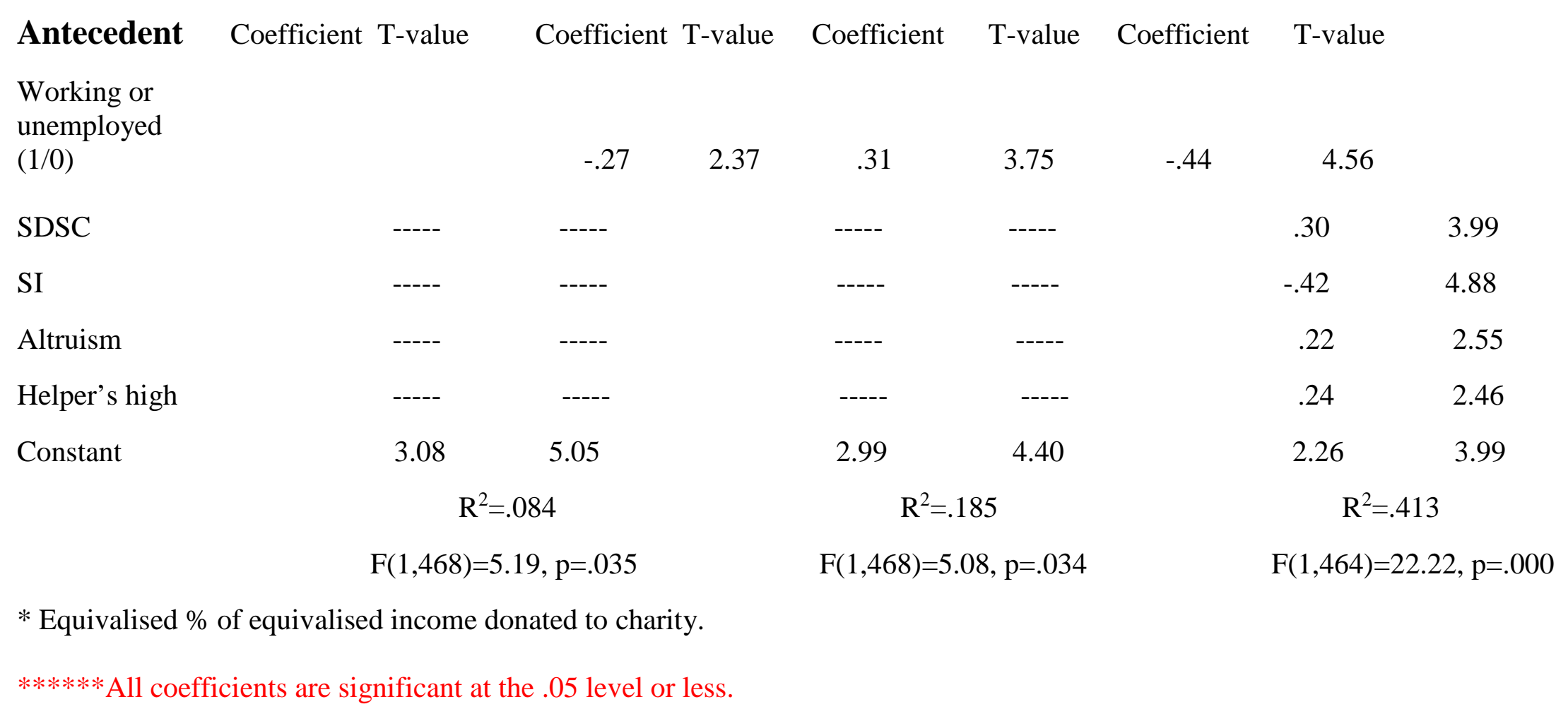


effect of the mediated pathway via SI ( $\mathrm{b}_{3 .} \mathrm{b}_{4=-} .13$, bootstrapped $\left.\mathrm{T}=4.45\right)$. Thus hypotheses 1 , 3, 4 and 5 are substantiated. The total indirect effect of employment status on the percentage of income donated ( $\left.b_{1} . b_{2}+b_{3} . b_{4}\right)$ was -.23 , and the total effect was -.7. Hence, the study participants who were in employment were on average .23 units lower in terms of the indirect effects of the mediators on the equivalised percentage of equivalised income donated to charity than the unemployed. The 95\% confidence interval for the difference between the two specific direct effects computed from the Hayes macro straddled zero (-1.25 to 2.01), indicating that the effects of the two mediators were not significantly different, i.e., the indirect effect of one pathway was essentially the same as the other. The analysis was rerun using non-equivalised data, the results following broadly the same pattern as those reported in Table 3.

\section{Conclusion}

Experiences of poverty are diverse and nowadays include (increasingly) the experiences of the working poor. Poverty, according to Hamilton et al. (2014) 'should be understood as a dynamic concept that is considered relative to the societal norms and customs of a given society’ (p.1834). Contemporary UK societal norms and customs seem to result, according to the findings of the present study, in many people who live below the poverty line but who are in employment, having substantially different outlooks, perspectives and overall world views to those of large numbers of people who are unemployed. In relation to charity giving, it appears that the life experiences of the working poor engender perspectives and attitudes that frequently cause these individuals to practice charity donation behaviour resembling that of the financially better-off more closely than that of the unemployed poor. The answer to research question one is positive since, on average, the working poor in the present study did donate proportionately less of their incomes to charity than participants who did not work. As regards research question two, the results indicate that a sense of social deprivation and/or of 
integration with the wider working world constitute significant and substantial influences on the financial donation behaviour of poor people (substantiating hypotheses four and five). However, the working poor, on the average, possessed greater feelings of social inclusion (confirming hypothesis one) and had lower self-concepts of belonging to a socially deprived community (H3). Overall, the outcomes to the study indicate that simply having a job (which presumably involves mixing and conversing with other working people) can give rise to outlooks on life that affect charity giving. The results are in line with prior studies of donor behaviour that personal altruism and helper's high exert major influences on the donation propensities of financially poor people (see Bennett, 2012).

\section{Theoretical implications}

These findings are important theoretically because they link concepts of social exclusion (Mathiesson et al., 2008) with donor behaviour. The unemployed, according to social exclusion theory, often lack feelings of self-worth due to their perceptions of being shut out from mainstream society and of being distant from cultural and social, as well as economic, systems (cf. Charity Commission, 2001; Brooks, 2002; Barnes, 2005; Mathieson et al., 2008). Theory predicts, moreover, that feelings of this nature can affect behaviour. The results of the current investigation are compatible with social exclusion theory. It seemed that unemployed sample members felt they were denied access to resources and opportunities available to other people and this encouraged them to view the world through a particular kind of lens (cf., Silver 1994; Duffy, 1995; Mathiesonet et al., 2008), resulting in their making relatively generous donations to charity. A common and interesting finding of a number of academic commercial-sector investigations of the buying behaviour of low-income consumers is that financially poor people often 'overspend' on certain discretionary spending items by amounts over and above what they can objectively afford. Might this phenomenon also apply to 
charity giving? If it does it might contribute to explaining the relative generosity of poor individuals when making charity donations.

The research also contributes to the wider literature on why some people opt to give to certain kinds of charity (animals, cancer, arts organisations, opera houses, international aid, human rights) whereas others choose to donate to quite different genres of cause. Distinct differences in people's choices based on personal characteristics have been identified in studies undertaken, among others, by Bennett (2003), Wiepking (2010), and Neumayr and Handy (2017). These studies found that 'individualistic' people were more likely to select the human rights nonprofit, whereas 'empathetic' participants were more likely to choose the cancer or the animal welfare charities. Higher social status individuals tended to give to cultural organisations, whilst politically left-of-centre people were inclined to donate to nonprofits that had an international focus.

\section{Practical implications}

In practical terms, the findings imply the need to craft any fundraising campaigns and messages aimed at the working poor in manners that differ from communications targeted at other groups of poor people; given the continuing rise in the numbers of working poor people and since the working poor possess particular characteristics that fundraisers need to recognise. As the proportion of working poor families in the overall population grows, the salience of the sector will increase vis-à-vis charity fundraising. This expansion of the 'tail end' of the donating public is clearly worth serious investigation. It is relevant to note in this connection the keen interest shown by commercial enterprises in the development of markets for branded products among poor people (see, for example, Bertrand, Mullainathan \& Shafir, 2006; Ghali \& Toukabri, 2014; Hamilton et al., 2014; Mack, 2017). Charity fundraisers might learn from businesses that sell to the poor in terms of how firms (in order to craft 
advertisements) examine the television viewing, newspaper readership, and social media usage of the poor (Simanis, 2009); actively seek to create sub-sections of this market; and take great care during campaigns not to be disrespectful or patronising towards poor families. The poor have been deliberately targeted by advertising campaigns to do with, inter alia, foodstuffs, gaming, certain types of clothing, alcohol and financial services. Commercial enterprises clearly recognise the potential value of the 'bottom of the pyramid' market.

Deliberate targeting of poor people by fundraising charities raises questions regarding the morality of soliciting donations from financially cash-strapped individuals whose gifts will make them even poorer. McQuillan (2016) examined (among other things) the ethicality of coaxing donations from individuals who cannot afford them. Donations from poor people are voluntary and result from laudable motives; and fundraisers are required to solicit gifts on behalf of their organisations' beneficiaries. McQuillin (2016) concluded that a balance must be struck between fundraisers' activities and the need to ensure that no harm is done to donors. It is relevant to note in this connection that, following a number of scandals involving aggressive charity solicitations of gifts from vulnerable people (see Etherington, 2016), a single UK Fundraising Regulator was established which issued a code of practice that prohibits asking vulnerable individuals for donations.

\section{Limitations and directions for future research}

Certain limitations apply to the research, which involved a relatively small sample in a single city in a period characterised by particular economic circumstances. Thus, replications of the study would be desirable, as would qualitative studies to explore in depth possible differences in SDSC and SI among groups of poor people with particular characteristics. Qualitative research might also investigate the potential for social desirability bias within responses, i.e., 
whether certain poor people exaggerate the amounts they give to charity in order to improve their self-esteem. Effective testing for social desirability bias requires the administration of additional psychological test inventories to survey participants, which was not possible within the constraints of the current investigation. Nevertheless, the percentages of the responses in various categories to items in the variables in the study that possessed social desirability connotations (altruism, giving levels and helper's high) were calculated, which revealed that the percentages of potentially socially desirable answers given never exceeded 21\%, indicating the absence of social desirability bias in the study outcomes.

Several other areas for further research can be suggested. For instance, do differences exist in the donation behaviour of working poor individuals in secure long-term employment compared with employees who are in casual jobs (cf. Kim, 1998)? How might giving behaviour change as the economy improves (or worsens)? Among the unemployed poor, does donation behaviour vary according to how long a person or family has been living on welfare, e.g., among families that have had no working member for two or three generations? Does the giving behaviour of poor people depend in part on their general consumption patterns and household budgeting practices (which typically differ from those of the better-off, especially in relation to entertainment, saving patterns, payments for housing and spending on certain foodstuffs)? Do differences exist between the employed and unemployed poor in the amounts of time they devote to voluntary charity activities (as opposed to money)? Do working poor individuals tend to prefer giving to particular types of good cause in comparison with the causes preferred by unemployed people? Clearly, there is much to learn about this crucial donor market. An interesting question for further research is whether working poor individuals tend to prefer giving to particular types of good cause in comparison with the causes preferred by unemployed people? For example, might the unemployed poor be driven on the average to donate to the kinds of charity from which they personally might be likely to 
need to seek assistance in the future, e.g., homelessness charities or food bank organisations? Do particular forms of poor people’s negative experiences of poverty-related problems (homelessness, vulnerability to crime, drug issues etc.) impact differentially on the donation behaviour of the working and unemployed poor? Do working and unemployed people have similar access to information (notably via mobile devices) about specific causes and charitable organisations? Clearly, there is much to learn about this crucial donor segment.

\section{References}

Alwitt, F. \& Donley, T. (1996). The low-income consumer: Adjusting the balance of exchange. New York: Sage.

Andreoni, J. (2006). Philanthropy. In S.Kolm \& J. Ythier (Eds.), Handbook of the economics of giving: Altruism and reciprocity (pp. 1201-1269). New York: Elsevier.

Banks, J. \& Tanner, S. (1997). The state of donation: Household gifts to charity 1974-96. London: The Institute for Fiscal Studies.

Barnes, M. (2005). Social exclusion in Great Britain: An empirical investigation and comparison with other European Union member states. Aldershot: Ashgate Publishing Ltd.

Bauman, Z. (2005). Work, consumerism and the new poor. Milton Keynes: Open University Press.

Bekkers, R. \& Wieping, P. (2011). A literature review of empirical studies of philanthropy: Eight mechanisms that drive charitable giving. Nonprofit and Voluntary Sector Quarterly, 40 (5), 924-973.

Belfield, C., Cribb, J., Hood, A. \& Joyce, R. (2015). Nearly two thirds of children in poverty live in working families. London: Institute for Fiscal Studies. Accessed on 10 September 2017 at www.ifs.org.uk.

Bennett, R. (2003). Factors underlying the inclination to donate to particular types of charity. International Journal of Nonprofit and Voluntary Sector Marketing, 8 (1), 12-29.

Bennett, R. (2012). Why urban poor donate: A study of low income charitable giving in London. Nonprofit and Voluntary Sector Marketing, 41(5), 870-891. 
Bennett, R. \& Barkensjo, A. (2005). Determining the design of child-specific adoption advertisements: A conjoint analysis. International Journal of Market Research, 47, 267-294.

Bennett, R. \& Gabriel, H. (1999). Charity involvement and customer preference for charity brands. Journal of Brand Management, 7 (1), 49-66.

Bertrand, M., Mullainathan, S. \& Shafir, E. (2006). Behavioural economics and marketing in aid of decision making among the poor. Journal of Public Policy and Marketing, 25 (1), 823.

Bingham, J. (2016). Working families are the 'new poor' says Britain's leading economic think tank. The Telegraph, 19 July 2016. Accessed on 11 September at www.thetelegraph.co.uk.

Brady, D., Fullerton, A. \& Cross, J. (2010). More than just nickels and dimes: A crosssectional analysis of working poverty in affluent democracy. Social Problems, 57(4), 559585.

Brooks, A. (2002). Welfare receipt and private charity. Public Budgeting and Finance, 22(3), 101-114.

Brooks, A. (2008). The poor give more. Portfolio, March 2008, pp.1-2.

Browne, J. \& Hood, A. (2016). Living standards, poverty and inequality in the UK: 2015/16 to 20120/21. IFS Report R114, March 2016. London: Institute for Fiscal Studies.

Bullock, H., Wyche, K. \& Williams, W. (2001). Media images of the poor. Journal of Social Issues, 57(2), 229-246.

Butler, P. (2017). Record 60\% of Britons in poverty are in working families - study. The Guardian, 22 May 2017. Accessed on 11 September 2017.

CAF (Charities Aid Foundation) (2015). UK Giving 2014. London: Charities Aid Foundation. Accessed on 13 September 2017 at www.cafonline.org.

CAF/VCVO (Charities Aid Foundation and National Council for Voluntary Organisations) (2008). UK Giving 2008. London: Charities Aid Foundation and the National Council for Voluntary Organizations.

Charity Commission (2001). The promotion of social inclusion. London: Charity Commission. Accessed on 11 September 2017 at www.gov.uk/government/organisations.

Chase, E. \& Walker, R. (2013). The co-construction of shame in the context of poverty: Beyond a threat to the social bond. Sociology, 47(4), 739-754.

Dilworth, S. (2013). Why are the poor more generous than the wealthy? Civil Society, 12 June 2013. Accessed on 11 September 2017 at www.civilsociety.co.uk.

Duffy, K. (1995). Social cohesion and human dignity in Europe. Strasbourg: Council of Europe.

DWP (Department for Work and Pensions) (2009). Households below average income (HBAI) 1994-2008. London: Department for Work and Pensions, http://research.dwp.gov.uk.

DWP (Department for Work and Pensions) (2016). Households below average income (HBAI) 1994-2015. London: Department for Work and Pensions, http://research.dwp.gov.uk 
Ehrenreich, B. (2001). Nickel and dimed: On (not) getting by in America. New York: Holt.

Etherington, S. (2015). Regulating fundraising for the future: Trust in charities, confidence in Fundraising Regulation. London: National Council for Voluntary Organisations, www.vcvo.org.uk.

EurWork (European Observatory of Working Life) (2010). Working poor in Europe: UK. Dublin: European Union.

Ghali, Z. \& Toukabri, M. (2014). Towards a better understanding of the behaviour of poor consumers: Exploratory study. International Journal of Research in Management and Business Studies, 1(1), 85-87.

Hamilton, K., Piacentini, M., Bannister, E., Barrios, A., Blocker, C., Coleman, C., Ekici, A., Gorge, H., Hutton, M., Passerard, F. \& Saatcioglu, B. (2014). Poverty in consumer culture: Towards a transformative social representation. Journal of Marketing Management, 30(1718), 1833-1857.

Harper, B. \& Tuckman, B. (2006). Racial identity beliefs and academic achievement: Does being black hold students back? Social Psychology of Education, 9, 381-403.

Hayes, A. (2013). Introduction to mediation, moderation and conditional process analysis: A regression-based approach. New York: Guilford Press.

Hill, R. (2002). Consumer culture and the culture of poverty: Implications for marketing theory and practice. Marketing Theory, 2(3), 273-293.

Horwitz, W. (2012). How does the media influence public attitudes to people in poverty? London: Community Links.

ILO (International Labour Organisation) (2015) Inclusive labour markets: Labour relations and working conditions. Geneva: ILO.

Kim, M. (1998). The working poor: Lousy jobs or lazy workers? Journal of Economic Issues, 32 (1), 65-78.

Larsen, C. \& Dejgaard, T. (2012). The institutional logic of images of the poor and welfare recipients: A comparative study of British, Swedish and Danish newspapers. Working Paper 2012-78, Stockholm: Centre for Comparative Welfare Studies.

Leana, C., Mittal, V. \& Stiehl, E. (2012). Organisational behaviour and the working poor. Organisation Science, 22 (3), 888-906.

Lee, R. \& Robbins, S. (1995). Measuring belongingness: The social connectedness and the social assurance scales. Journal of Counselling Psychology, 42(2), 232-241.

Lerner, M. (2013). In hard times: People who grew up poor spend more, cut less. Daily Finance, 5 April 2013. Accessed on 11 March 2015 at www.dailyfinance.com.

McGuiness, F. (2016). Poverty in the UK: Statistics. House of Commons Briefing Paper 7096. London: House of Commons.

McKenzie, T. \& Pharoah, C. (2011). How generous is the UK? Charitable giving in the context of household spending. Centre for Charitable Giving Briefing Note 7. London: Cass Business School Centre for Charitable Giving. 
McQuillin, I. (2016). Rights stuff: Fundraising's ethics gap and a new normative theory of fundraising ethics. Plymouth: Centre for Sustainable Philanthropy, Plymouth University.

Mack, S. (2007). Negative and direct marketing to poor people. Small Business Chronicle, January 2017, 1-5. Accessed on 21September 2017 at www.smallbusiness.chron.com.

Mathieson, J., Popay, J., Etheline, E., Escorel, S., Hernandez, M., Johnston, H. \& Rispel, L. (2008). Social exclusion meaning, measurement and experiences and links to health inequalities: A review of literature. Lancaster University, World Health Organisation.

Mayo, J. \& Tinsley, C. (2009). Warm glow and charitable giving: Why the wealthy do not give more to charity? Journal of Economic Psychology, 30, 490-499.

Micklewright, J. \& Schnepf, S. (2007). Who gives for overseas development? Discussion Paper 3057, Institute for the Study of Labour. Bonn: University of Bonn.

Morris, N. (2014). Working poor trapped in unbreakable cycle of poverty turn to food banks in their lunch breaks. The Independent, 10 February 2014. Accessed on 10 September 2017 at www.independent.uk.

Moscovici, S. (1988). Notes towards a description of social representations, European Journal of Social Psychology. 18, 211-250.

O’Brian, D., Wilkes, J., De Haan, A. \& Maxwell, S. (2009). Poverty and social exclusion in North and South. University of Sussex: Institute of Development Studies.

ONS (Office for National Statistics) (2017). Personal and household finances. Newport, UK: Office for National Statistics. Accessed on 14 September 2017 at www.ons.gov.uk.

Ostrower, F. (1997). Why the wealthy give: The culture of elite philanthropy. Princeton NJ: Princeton University Press.

Padley, M. \& Hirsch, D. (2017). A minimum standard for the UK in 2017. York: Joseph Rowntree Foundation.

Piff, P., Kraus, W., Cote, S., Cheng, B. \& Keltner, D. (2010). Having less, giving more: The influence of social class on prosocial behaviour, Journal of Personality and Social Psychology. 99 (5), 771-784.

Pudelek, J. (2013). Poorest people give highest proportion of income to charity, says study. Third Sector, 3 April 2013. Accessed on 11 September 2017 at www.thirdsector.co.uk.

Radley, A. \& Kennedy, M. (1995). Charity giving by individuals: A study of attitudes and practice. Human Relations, 48(6), 685-709.

Reed, A. (2004). Activating the self-importance of consumer selves: Exploring identity salience effects on judgements. Journal of Consumer Research, 31(2), 286-295.

Rodriguez, T. (2002). Oppositional culture and academic performance among children of immigrants in the USA. Race, Ethnicity and Education, 5(2), 199-215.

Sargeant, A. (1999). Charitable giving: Towards a model of donor behaviour. Journal of MarketingManagement, 15, 215-238.

Sargeant, A. \& Woodliffe, L. (2007). Gift giving: An interdisciplinary review. International Journal of Nonprofit and Voluntary Sector Marketing, 12, 275-307. 
Savchuk, K. (2014). Wealthy Americans are giving less of their income to charity while poor are donating more. Forbes Magazine, 6 October 2014. Accessed on 10 September 2017 at www.forbes.com/sites/katiasavchuk.

Schwartz, S. (1977). Normative influences on altruism. In L. Berkowitz (Ed.), Advances in Experimental Social Psychology (Vol. 10, pp. 221-279). New York, NY: Academic Press.

Silver, H. (1994). Social exclusion and social solidarity. International Labour Review, 133 (5-6), 531-578.

Simanis, E. (2009). At the base of the pyramid. The Wall Street Journal, 26 October 2009, 13. Accessed on 20 September 2017 at www.wsk.com.

Skarmeas, D. and Shabbir, H. (2011). Relationship quality and giving behaviour in the UK fundraising sector: Exploring the antecedent roles of religiosity and self-construal. European Journal of Marketing, 45 (3), 720-738.

Slack, B. (2005). Banking on it. Charity Times, June 2005, p. 37.

Steele, C. (1998). Stereotyping and its threat are real. American Psychologist, 53, 680-691.

Stern, K. (2013). Why the rich don't give to charity. The Atlantic, April 2013. Accessed on 10 September 2017 at www.theatlantic.com.

Topham, G. (2014). Record numbers of working families in poverty due to low paid jobs. The Guardian, 24 November 2014, p.1. Accessed on 10 March 2015 at www.theguardian.com/society.

US Department of Labour (2009). A profile of the working poor. Washington: US Bureau of Labour Statistics.

Walker, P. (2016). Study finds 7 million Britons in poverty despite being in working families. The Guardian, 7 December 2016. Accessed on 11 September 2017 at www.the guardian.co.uk.

Walker, C. \& Pharoah, C. (2002). A lot to give: Trends in charitable giving for the 21st Century. London: Hodder and Stoughton.

Wiepking, P. (2007). The philanthropic poor: In search of explanations for the relative generosity of lower income households. Voluntas, 18, 339-358.

Wilson, W. (1997). When work disappears: The world of the new urban poor. New York: Knopf.

World Bank (2013). Inclusion matters: The foundation for shared prosperity. Washington DC: World Bank. 